Available online @ https://jiem.jnnce.ac.in

https:www.doi.org/10.37314/JJEM.2021.050106

Indexed in International Scientific Indiexing (ISI)

Impact factor: 1.025 for 2018-19

Published on: 30 September 2021

\title{
Water Quality Index of Tunga River in Shivamogga
}

\author{
Sreenivasa $\mathbf{V}^{1}, \quad$ Bindiya $\mathbf{K}^{2}$ \\ ${ }^{1,2}$ Department of Civil Engineering, \\ JNN College of Engineering, Shimoga, Karnataka, India \\ srinivasajetty.v@jnnce.ac.in, bindiyak @jnnce.ac.in
}

\begin{abstract}
River Tunga flowing near Shivamogga City, Karnataka State, India, receives waste water discharges from villages located on the bank of River and industries located along the stretch. The present study involves to determine the water quality index of polluted our selected stretch of River. Water samples were collected from different locations and analyzed for physical- chemical parameters like $\mathrm{pH}$, Alkalinity, total hardness, Electrical Conductivity, Calcium ions, magnesium ions and total dissolved solids. All the physical and chemical parameters were compared with the standard Values of IS. These chemical and physical parameters substituted in the WQI equation. WQI facilitates a single numeric value that defines overall water quality for a definite location. The WQI of Tunga River in Shivamogga city vary from 50.38 to 85.48
\end{abstract}

Keywords: Shivamogga, Water Quality Index, assessment

\section{Introduction}

According to World Health Organization, about $80 \%$ of all diseases in human beings are caused by water. In India, according to Niti Aayog over two lakh people die of water born disease annually. According to report of United Nations the water quality in India is poor and it ranks $120^{\text {th }}$ among 122 nations in terms of quality of water available to its citizens. Karnataka human development report (2005) by Government of Karnataka reported $18.63 \%$ people of Shivamogga district lack of safe drinking water.

The Tunga River is one of the major sources of drinking water for peoples of Shivamogga. It is a livelihood to many professions and critical to their survival. In this regard it is essential to put efforts to assess the quality of Tunga River. Many Water Quality studies concentrated on small lakes, ground water and small city stretch of river in Shivamogga region. Present studies aiming at water quality along overall length of river.

Agricultural wastes, Industrial effluents, domestic sewage are released to river. Hence water quality is decreasing and leading to water born diseases. Pollution of Tunga River had affected direct or indirectly more than lakhs of people in the sub-basin as most villages use the river water for drinking, bating, irrigation crops, fishing and livestock.

River water quality can be restored by avoiding pollutants to enter. If not it has even direct impact on flora and fauna. The use of modern pesticides, herbicides and fertilizers is polluting the river, thereby impact the overall productivity of the agricultural land. It causes a severe loss of export revenue also. Water Quality of river can be measured effectively by using WQI. 


\section{Study Area}

Shivamogga is District located in Central Karnataka state between $13^{\circ} 27^{\prime}$ and $14^{0} 39^{\prime} \mathrm{N}$ Latitude and $74^{\circ} 38^{\prime}$ and $74^{\circ} 04^{\prime}$ 'E Longitude covers an area of 8495 sq.km. Figure 1 shows the location of Shivamogga District in Karnataka State.

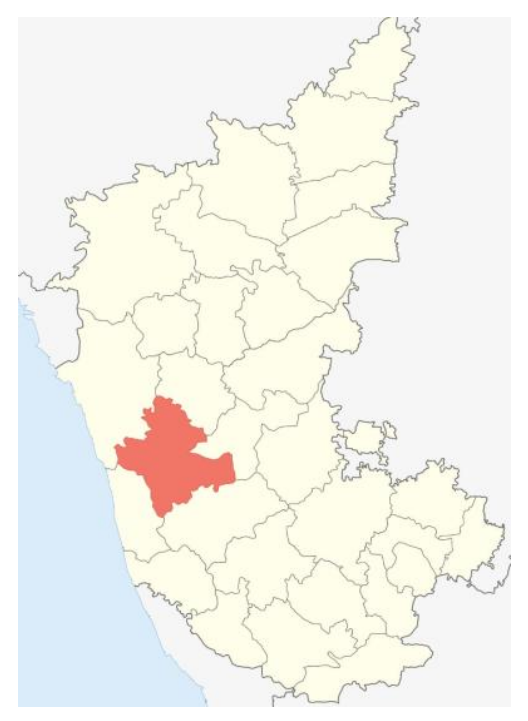

Figure 1: Location of Study Area

The horticulture, agriculture and animal husbandry is the major sources of employment in Shivamogga, which engage $80 \%$ of the workforce. The major industries are iron and steel, paper, foundries and rice mills. Highly weathered Schist and gneiss form the geology of the area.

The Tunga River originates in the Western Ghats, on a hill known as Varaha Parvata, at a place called Ganga Moola of Chikmaglur district in Karnataka state. The Gangamoola hill is surrounded by thick forests called as Bhagavathi forest. From here, the river flows through four districts in Karnataka, Dakshina Kannada, Udupi, Chikmagalur and Shimoga. The River Tunga merges with the Bhadra River at Koodli, a small village near Shimoga. The river is given the compound name Tungabhadra from this point onwards. The Tungabhadra flows eastwards and merges with the Krishna River in Andhra Pradesh.
Tunga river is a river flows $180 \mathrm{~km}$ through Shivamogga. Following are the places directly benefited by the Tunga river. Sringeri, Hariharapura, Mulur, Theertahalli, Mandagadde, Sakrebailu, Harakere, Shivamogga, Kudli, Holalur, Saswehalli,Honnali, Ukkadagatri, Sirigere, Harihar. After Kudli the river is considered as Tunga-Bhadra. Figure 2 shows the stretch of the Tunga River.

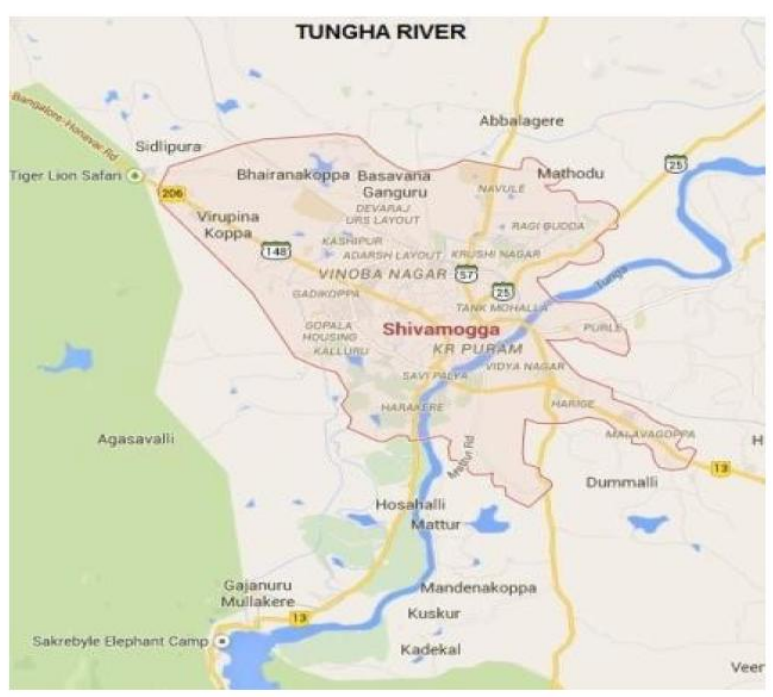

Figure 2: Tunga River Stretch

\section{Methodology}

During pre monsoon period, water samples were collected from different locations along length of river. Present work is aimed at assessing the Water-Quality Index (WQI) for the surface river water of Shivamogga District. Samples are collected and subjected to physiochemical analysis.

At five locations, samples are collected as per IS code 3025 and subjected to physiochemical analysis. Each of the samples is tested for quality of drinking water as per Indian Standard code 10500 and Water Quality Index is determined. For calculating WQI eight water quality parameters will be considered.

Quality rating scale : $\mathrm{qi}=(\mathrm{Ci} / \mathrm{Si}) * 100$

qi $=$ Quality Rating,

$\mathrm{Ci}=$ Concentration of each chemical parameter in each water sample, 
$\mathrm{Si}=$ Indian Standard

Sub index of $i^{\text {th }}$ parameter : SIi $=$ Wi.qi

Water Quality Index $=$ WQI $=\Sigma$ SIi

Figure 1 shows the flow diagram of the proposed system.

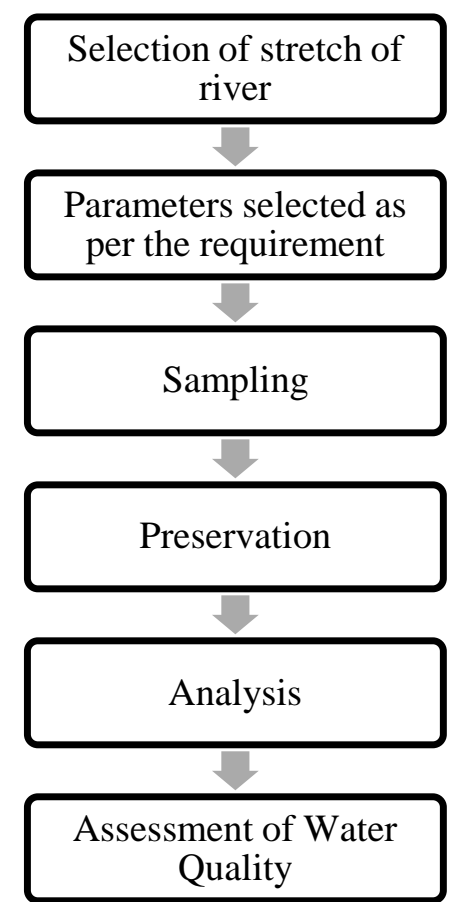

Figure 1: Flow diagram of the proposed system

\section{Sampling Stations}

\section{Station - S1: details}

Mathur is a village in Shivamogga district near the city of Shivamogga, Mathur has a temple of rama, hosahalli is situated across the bank of the tunga river.

\section{Station - S2 details}

Station S2 is an upstream station and located near the Shimoga - Thirthahalli new bridge i.e., on the north side of the river. Water is being drawn for supply to the town from this station.

\section{Station - S3 details}

The station S3 is located near ayappa Swamy temple (Ramanna Shetty park). A bathing ghat exists near this Station and is the downstream of the sewage disposal point. Station S3 is a most affected station.

\section{Station - S4 details}

Station S4 is located on the south side of the river, near the Shimoga - Bhadravathi new bridge. Two number of sewage drains dispose city sewage water in to the river directly.

\section{Station - S5 details}

Kodli is a small town near Shivamogga City, Karnataka. It is $147 \mathrm{Km}$ long and merges with the Bhadra river at koodli.

\section{Assessment of water-quality}

The chemical, physical and biological characteristics of water is referred as water quality. It is a measure of the condition of water relative to the requirements of living animals. It is most frequently used by reference to a set of standards against which compliance can be assessed. The most common standards used to assess water quality relate to health of ecosystems, safety of human contact and drinking water.

The overall Water Quality Index was calculated by aggregating the quality rating with the unit weight linearly (Equation 1).

$$
\mathbf{W Q I}=\frac{\sum \mathbf{q} \mathbf{n} \mathbf{W} \mathbf{n}}{\sum \mathbf{W} \mathbf{n}}
$$

Table 1 shows the water quality index and status of water quality.

Table 1: Water Quality Index (WQI) and status of water quality

\begin{tabular}{|c|c|}
\hline $\begin{array}{c}\text { Water quality } \\
\text { Index Level }\end{array}$ & $\begin{array}{c}\text { Water Quality } \\
\text { Status }\end{array}$ \\
\hline $0-25$ & $\begin{array}{c}\text { Excellent water } \\
\text { quality }\end{array}$ \\
\hline $26-50$ & $\begin{array}{c}\text { Good water } \\
\text { quality }\end{array}$ \\
\hline $51-75$ & $\begin{array}{c}\text { Poor water qual- } \\
\text { ity }\end{array}$ \\
\hline $76-100$ & $\begin{array}{c}\text { Very Poor water } \\
\text { quality }\end{array}$ \\
\hline$>100$ & $\begin{array}{c}\text { Unsuitable for } \\
\text { drinking }\end{array}$ \\
\hline
\end{tabular}

The following are the parameters are 
considered for evaluating water quality index of Tunga River.

Determination of:

$>\mathrm{Ph}$

$>$ Electric conductivity (EC)

$>$ Turbidity

$>$ Total hardness

$>$ Calcium

$>$ Magnesium

$>$ Sulphate

$>$ Iron

\section{Results and discussion}

The quality of water varies from location to location. Table 1 represents status of Water Quality as per Water Quality Index. WHO and ISI standards are represented by Table 2 along with Sample station 01 values. The water quality index of all the five station points are discusses below from table 3 to 7 . Sample calculation shown in table 3 .
Table 2: Water quality parameters and there WHO and ISI standards

\begin{tabular}{|l|c|c|c|}
\hline Parameters & $\begin{array}{c}\text { WHO } \\
\text { standards }\end{array}$ & $\begin{array}{c}\text { ISI } \\
\text { stand- } \\
\text { ards }\end{array}$ & $\begin{array}{c}\text { Sample } \\
\text { Station- } \\
\mathbf{0 1}\end{array}$ \\
\hline Ph & $7.0-8.0$ & $6.5-8.5$ & 7.03 \\
\hline $\begin{array}{l}\text { Electrical } \\
\text { conductivity } \\
\text { (ms/m) }\end{array}$ & $\begin{array}{l}1.400 \\
\mathrm{~d} / \mathrm{s} / \mathrm{m}\end{array}$ & 300 & 87.83 \\
\hline $\begin{array}{l}\text { Turbidity } \\
\text { (NTU) }\end{array}$ & 5 & 5 & 2.13 \\
\hline $\begin{array}{l}\text { Hardness } \\
\text { (mg/l) }\end{array}$ & 100 & 300 & 71.3 \\
\hline $\begin{array}{l}\text { Calcium } \\
\text { (mg/l) }\end{array}$ & 75 & 75 & 38 \\
\hline $\begin{array}{l}\text { Magnesium } \\
\text { (mg/l) }\end{array}$ & 150 & 30 & 33.33 \\
\hline $\begin{array}{l}\text { Sulphate } \\
\text { (mg/l) }\end{array}$ & 400 & 200 & 253.82 \\
\hline $\begin{array}{l}\text { Iron } \\
\text { (mg/l) }\end{array}$ & 0.3 & 0.3 & 0 \\
\hline
\end{tabular}

Table 3: Calculation of WQI (Wqn) for Station-01

\begin{tabular}{|c|c|c|c|c|c|}
\hline Parameters & $\begin{array}{c}\text { Values } \\
\mathbf{V}_{\mathbf{n}}\end{array}$ & $\begin{array}{c}\text { Standard } \\
\text { values }\end{array}$ & $\begin{array}{c}\text { Unit } \\
\text { weight } \\
\mathbf{W}_{\mathbf{n}} \\
\end{array}$ & $\begin{array}{c}\text { Quality } \\
\text { Rating } \\
\left(q_{n}\right)\end{array}$ & $\begin{array}{c}\text { Weighted } \\
\text { values } \\
\left(\mathbf{W}_{\mathbf{n}} \mathbf{q}_{\mathbf{n}}\right) \\
\end{array}$ \\
\hline $\mathrm{Ph}$ & 7.03 & 8.5 & 0.12 & 2 & 0.24 \\
\hline $\begin{array}{l}\text { Electrical conductivity } \\
\mathrm{ms} / \mathrm{m}\end{array}$ & 87.83 & 300 & 0.003 & 28.94 & 0.09 \\
\hline Turbidity NTU & 2.13 & 5 & 0.2 & 287 & 57.4 \\
\hline Hardness mg/l & 71.3 & 300 & 0.003 & 114.35 & 0.38 \\
\hline Calcium mg/l & 38 & 75 & 0.013 & 3700 & 49.32 \\
\hline Magnesium mg/l & 33.33 & 30 & 0.03 & 2.775 & 0.09 \\
\hline Sulphate $\mathrm{mg} / \mathrm{l}$ & 253.82 & 200 & 0.05 & 26.91 & 1.34 \\
\hline \multirow[t]{2}{*}{ Iron $\mathrm{mg} / \mathrm{l}$} & 0 & 30 & 3.33 & 30 & 99.99 \\
\hline & & \multicolumn{2}{|c|}{$\sum \mathbf{W}_{\mathbf{n}}=\mathbf{3 . 7 5}$} & \multicolumn{2}{|c|}{$\sum \mathbf{W}_{n} q_{n}=208.87$} \\
\hline
\end{tabular}


Table 4: Calculation of WQI (Wqn) for stations-02

\begin{tabular}{|c|c|c|c|}
\hline Parameters & $\mathbf{V}_{\mathbf{n}}$ & $\mathbf{q}_{\mathbf{n}}$ & $\mathbf{W}_{\mathrm{n}} \mathbf{q}_{\mathrm{n}}$ \\
\hline $\mathrm{Ph}$ & 7.73 & 48.66 & 5.72 \\
\hline Electrical conductivity, $\mathrm{ms} / \mathrm{m}$ & 100.44 & 33.16 & 0.11 \\
\hline Turbidity, NTU & 1.2 & 380 & 76 \\
\hline Hardness $\mathrm{mg} / \mathrm{l}$ & 164 & 68 & 0.23 \\
\hline Calcium & 36.66 & 3834 & 51.11 \\
\hline Magnesium $\mathrm{mg} / \mathrm{l}$ & 127.33 & 81.10 & 2.70 \\
\hline Sulphate & 147.06 & 26.47 & 1.32 \\
\hline \multirow[t]{3}{*}{ Iron } & 0.03 & 27 & 89.99 \\
\hline & \multicolumn{3}{|c|}{$\sum \mathbf{W}_{\mathbf{n}} \mathbf{q}_{\mathbf{n}}=227.1956433$} \\
\hline & \multicolumn{3}{|c|}{$\mathrm{WQI}=60.51601636$} \\
\hline
\end{tabular}

Table 5: Calculation of WQI (Wqn) for stations-03

\begin{tabular}{|c|c|c|c|}
\hline Parameters & $\mathbf{V}_{\mathbf{n}}$ & $\mathbf{q}_{\mathbf{n}}$ & $\mathbf{W}_{\mathbf{n}} \mathbf{q}_{\mathbf{n}}$ \\
\hline $\mathrm{Ph}$ & 7.5 & 33.33 & 3.92 \\
\hline Electrical conductivity $\mathrm{ms} / \mathrm{m}$ & 273.73 & 91.06 & 0.30 \\
\hline Turbidity, NTU & 14.9 & 990 & 198 \\
\hline Hardness $\quad \mathrm{mg} / \mathrm{l}$ & 160 & 70 & 0.23 \\
\hline Calcium $\mathrm{mg} / \mathrm{l}$ & 59 & 1600 & 21.33 \\
\hline Magnesium $\mathrm{mg} / \mathrm{l}$ & 101 & 59.16 & 1.97 \\
\hline Sulphate & 125.95 & 37.02 & 1.85 \\
\hline Iron & 0.02 & 28 & 93.33 \\
\hline & \multicolumn{3}{|c|}{$\sum \mathbf{W}_{\mathbf{n}} \mathbf{q}_{\mathbf{n}}=320.94$} \\
\hline & \multicolumn{3}{|c|}{$\mathrm{WQI}=85.48$} \\
\hline
\end{tabular}

Table 6: Calculation of WQI (Wqn) for stations-04

\begin{tabular}{|c|c|c|c|c|}
\hline \multicolumn{2}{|c|}{ Parameters } & $\mathbf{V}_{\mathbf{n}}$ & $\mathbf{q}_{\mathbf{n}}$ & $\mathbf{W}_{\mathrm{n}} \mathbf{q}_{\mathrm{n}}$ \\
\hline \multicolumn{2}{|l|}{$\mathrm{Ph}$} & 6.93 & 4.66 & 0.55 \\
\hline \multicolumn{2}{|c|}{ Electrical conductivity $\mathrm{ms} / \mathrm{m}$} & 175.87 & 58.43 & 0.19 \\
\hline \multicolumn{2}{|c|}{ Turbidity, NTU } & 2.5 & 250 & 50 \\
\hline Hardness & $\mathrm{mg} / \mathrm{l}$ & 86.66 & 106.67 & 0.36 \\
\hline Calcium & $\mathrm{mg} / \mathrm{l}$ & 47.33 & 2767 & 36.88 \\
\hline Magnesium & $\mathrm{mg} / \mathrm{l}$ & 39.33 & 7.77 & 0.26 \\
\hline Sulphate & $\mathrm{mg} / \mathrm{l}$ & 236.15 & 18.07 & 0.90 \\
\hline \multirow{3}{*}{\multicolumn{2}{|c|}{ Iron }} & 0 & 30 & 99.99 \\
\hline & & \multicolumn{3}{|c|}{$\sum \mathbf{W}_{\mathbf{n}} \mathbf{q}_{\mathbf{n}}=189.1450874$} \\
\hline & & \multicolumn{3}{|c|}{$\mathrm{WQI}=50.38083933$} \\
\hline
\end{tabular}


Table 7: Calculation of WQI (Wqn) for stations-05

\begin{tabular}{|c|c|c|c|}
\hline Parameters & $\mathbf{V}_{\mathbf{n}}$ & $\mathbf{q}_{\mathbf{n}}$ & $\mathbf{W}_{\mathrm{n}} \mathbf{q}_{\mathrm{n}}$ \\
\hline $\mathrm{Ph}$ & 8.5 & 100 & 11.76 \\
\hline Electrical conductivityms/m & 195.3 & 64.93 & 0.22 \\
\hline Turbidity NTU & 2.5 & 250 & 50 \\
\hline Hardness $\mathrm{mg} / \mathrm{l}$ & 106 & 97 & 0.32 \\
\hline Calcium $\mathrm{mg} / \mathrm{l}$ & 52 & 2300 & 30.66 \\
\hline Magnesium $\mathrm{mg} / \mathrm{l}$ & 54 & 20 & 0.67 \\
\hline Sulphate & 213.88 & 6.94 & 0.35 \\
\hline Iron & 0 & 30 & 99.99 \\
\hline & \multicolumn{3}{|c|}{$\sum \mathbf{W}_{\mathbf{n}} \mathbf{q}_{\mathbf{n}}=193.98$} \\
\hline & \multicolumn{3}{|c|}{ WQI=51.67 } \\
\hline
\end{tabular}

\section{Conclusions}

$>$ The quality of water is poor where it is considered to be least polluted.

$>$ The WQI vary from 50.38 to 85.48 as given in Table 8.

Table 8: WQI values for different stations

\begin{tabular}{|c|c|}
\hline Station & WQI values \\
\hline 1 & 55.64 \\
\hline 2 & 60.52 \\
\hline 3 & 85.48 \\
\hline 4 & 50.38 \\
\hline 5 & 51.67 \\
\hline
\end{tabular}

Therefore not recommended without treatment

\section{Limitation and Scope of Future Studies}

The work is limited to Tunga river within Shivamogga District, however work can be extended for TungaBhadra of $531 \mathrm{~km}$ within Karnataka.

The work is excluding biological characteristics of water like Biological Oxygen Demand (B.O.D) and Chemical Oxygen Demand (C.O.D).

\section{Acknowledgement}

We extend sincere thanks to the college authorities to conduct the present study.

\section{References:}

1. AartiMaheshwari., Manish Sharma, and Deepak Sharma, "Hydro Chemical Analysis of Surface and Ground Water Quality of Yamuna River at Agra, India,'J.Master .Environ. Sci., Vol. 24, pp. 373-378, 2011.

2. Anima Upadhyay, Chandrakala M, 2017, Water Quality Index of Ganga River Water, Rishikesh, Uttarakhand, India.

3. Ashwani Kumar and Anish dua, 2012, An introduction to Water Quality index for assessment of river, pg. (1)

4. Dr. H. S. Govardhan Swamy, 2015, River Water Pollution: A Case Study on Tunga River at Shimoga-Karnataka.

5. Dojlido, 1994, Gupta, 2003 and Avvannavar \& Shrihari, 2007, WQI was applied to river water as well as coastal water. 
6. IS: 10500 , water quality testing

7. Minakshi Bora, 2016, Water quality assessment in terms of water quality index (WQI) case study of the Kalong River, Assam, India.

8. Namita 2017, Sajitha V. 2016, SS Sagar2015. and Devendra Dohare 2014, Water quality parameters included in water quality assessment.

9. Shoji 1966 and Harkin, 1974, the different statistical approaches were followed for analyzing water quality data based on rank order of observations and factor analysis.
10. Shweta Tyagi, Bhavtosh Sharma, 2013, Prashant Singh, Rajendra Dobhal, Water Quality Assessment in Terms of Water Quality Index.

11. Namita 2017, Sajitha V. 2016, SS Sagar2015. and Devendra Dohare 2014, Water quality parameters included in water quality assessment 